\title{
Relationships among Contrasting Measurements of Microbial Dynamics in Pasture and Organic Farm Soils
}

\author{
S. L. Edenborn, ${ }^{1}$ A. J. Sexstone, ${ }^{2}$ Y. Sutanto, ${ }^{2}$ and J. A. Chapman ${ }^{2}$ \\ ${ }^{1}$ Department of Biology, Chatham University, Pittsburgh, PA 15232, USA \\ ${ }^{2}$ Division of Plant and Soil Sciences, West Virginia University, Morgantown, WV 26506-6108, USA
}

Correspondence should be addressed to A. J. Sexstone, alan.sexstone@mail.wvu.edu

Received 1 March 2011; Revised 16 May 2011; Accepted 20 May 2011

Academic Editor: M. Miransari

Copyright ( $) 2011$ S. L. Edenborn et al. This is an open access article distributed under the Creative Commons Attribution License, which permits unrestricted use, distribution, and reproduction in any medium, provided the original work is properly cited.

\begin{abstract}
Soil bacteria exhibit short-term variations in community structure, providing an indication of anthropogenic disturbances. In this study, microbial biomass carbon (MBC), potentially mineralizable nitrogen (PMN), community level physiological profiling (CLPP), and culture-dependent DGGE (CD DGGE) fingerprinting of the 16S rRNA gene were used to compare microbial communities in organic farm and pasture soils subjected to differing agronomic treatments. Correlation analyses revealed significant relationships between $\mathrm{MBC}, \mathrm{PMN}$, and data derived from microbial community analyses. All measures separated soil types but varied in their ability to distinguish among treatments within a soil type. Overall, MBC, PMN, and CLPP were most responsive to compost and manure amendments, while CD DGGE resolved differences in legume cropping and inorganic fertilization. The results support the hypothesis that culturable soil bacteria are a responsive fraction of the total microbial community, sensitive to agronomic perturbations and amenable to further studies aimed at linking community structure with soil functions.
\end{abstract}

\section{Introduction}

Microorganisms play essential roles in organic matter decomposition, nutrient cycling, and plant productivity [1, 2]. Parameters that integrate diverse microbial populations into a single measure, such as microbial biomass carbon (MBC) and potentially mineralizable nitrogen (PMN), historically have proven to be useful and are widely employed measures of soil quality [3, 4]. Microbial biomass C encompasses a small labile fraction of total soil organic carbon that responds actively to changes in soil fertility, supports soil aggregation, and can be related to environmental factors such as climate, soil moisture, texture, and organic matter quality [5]. Potentially mineralizable nitrogen provides an index of a soil's nitrogen-supplying capacity and has been positively correlated with other chemical and physical indicators of soil quality [4].

Various measures of functional and structural diversity in microbial communities have been proposed as appropriate indicators of changing soil quality $[3,6]$. Communitylevel physiological profiling (CLPP) measures soil functional diversity by characterizing the relative utilization of a suite of carbon substrates. Community-level physiological profiling is a culture-based enrichment method that primarily characterizes and selects for fast-growing organisms that may be distinct from dominant bacteria in soil inocula $[7,8]$; therefore, the ecological significance of CLPP data sometimes is questioned $[9,10]$. However, numerous studies have shown that CLPP is appropriately responsive to a wide variety of agronomic perturbations [11-18].

Several methodologies have been developed to characterize microbial structural diversity that rely on nucleic acid extraction followed by gene amplification and community fingerprinting $[19,20]$. Fingerprinting techniques cannot resolve total species richness and only profile a small fraction of the total bacterial diversity depending on the resolution of each individual method [21, 22]. A current paradigm states that culture-independent molecular methods provide a better representation of soil bacterial communities, since theoretically they include novel, numerically abundant, but difficult-to-culture groups such as the Acidobacteria and Verrucomicrobia [23-26]. However, an alternate hypothesis 
suggests that fingerprints of readily culturable bacteria may be more responsive to anthropogenic perturbations since they often exhibit rapid growth and produce substantial biomass [27]. Recently, we investigated a plate wash method to construct culture-dependent denaturing gradient gel electrophoresis (CD DGGE) profiles of the 16S rRNA gene [28]. We reported that CD DGGE profiled distinct fractions of the soil bacterial community that were not captured using culture-independent DGGE. In addition, the CD DGGE gels showed clear banding patterns of sufficient complexity and variability to investigate differences in microbial communities. The objectives of the present paper were to: (1) examine the responsiveness of CD DGGE fingerprints from pasture and organic farm soils that have been exposed to differing fertility regimes and (2) explore potential relationships between the CD DGGE profiles and MBC, PMN, and CLPP.

\section{Materials and Methods}

2.1. Description of Field Sites. The West Virginia University (WVU) Organic Research Farm is located in Monongalia County, West Virginia, United States of America $\left(39^{\circ} 38^{\prime}\right.$ $\left.34^{\prime \prime} \mathrm{N}, 79^{\circ} 56^{\prime} 04^{\prime \prime} \mathrm{W}\right)$. Soils on the farm are Dormont and Guernsey silt loams (fine loamy mixed, superactive, mesic, Oxyaquic Hapludalfs) [29]. The market garden has a completely randomized design with four plots $(4.9 \times 7.6 \mathrm{~m})$ per treatment [30]. Treatments included fertility input (compost and green manure) and annual crop rotation among four plant families (Fabaceae, Solanaceae, Cucurbitaceae, and Asteraceae). High-input plots received composted dairy manure (composted 1:1 cow manure and leaf litter applied at $22.4 \mathrm{Mg} \mathrm{ha}^{-1}$ based on wet weight), and green manure comprised of approximately equal parts rye (Secale cereale) and vetch (Vicia villosa) applied at approximately $10 \mathrm{Mg}$ $\mathrm{ha}^{-1}$ and tilled into the soil 1-3 days prior to planting. Lowinput plots received only green manure applied as described above. Treatments were applied to plots in late April and early May. Details of compost analyses, soil fertility, and crop yield in these plots have previously been reported by Childers [30].

The West Virginia University Reedsville Experiment Farm is located in Preston County, West Virginia, United States of America $\left(39^{\circ} 30^{\prime} 55^{\prime \prime} \mathrm{N}, 79^{\circ} 48^{\prime} 70^{\prime \prime} \mathrm{W}\right)$. Soils on the farm are mapped in the Gilpin (fine-loamy, mixed, semiactive, mesic Typic Hapludults) and Wharton (fineloamy, mixed, mesic Aquic Hapludults) soil series [29]. Over the past decade, this experimental pasture has been limed to maintain a $\mathrm{pH}$ circa 6.5 and fertilized with two levels of inorganic fertilizer inputs, that is, high fertility (P $134 \mathrm{~kg}$ $\mathrm{ha}^{-1}$ and $\mathrm{K} 390 \mathrm{~kg} \mathrm{ha}^{-1}$ ) or low fertility (P $67 \mathrm{~kg} \mathrm{ha}^{-1}$ and $\mathrm{K} 195 \mathrm{~kg} \mathrm{ha}^{-1}$ ). The predominant pasture grasses were orchard grass (Dactylis glomerata), Kentucky bluegrass (Poa pratensis), and meadow fescue (Festuca elatior) interspersed with white clover (Trifolium repens) and red clover (Trifolium pratense). The percentage of legumes averaged $36 \%$ and $10 \%$ in high- and low-fertility plots, respectively [31].

2.2. Soil Sampling. On the WVU Organic Research Farm composite (12 cores), surface soil samples $(15 \mathrm{~cm}$ depth $\times$
$2.5 \mathrm{~cm}$ diameter) were collected in June and August from each of high- and low-input plot that had been planted with beans (Phaseolus vulgaris), peas (Pisum sativum), and tomatoes (Lycopersicon esculentum) and peppers (Capsicum annuum). Ten soil cores $(16 \mathrm{~cm}$ depth $\times 2 \mathrm{~cm}$ diameter) were collected from each plot at $\sim 1.5$ meter intervals along two transects at the midpoint between crop rows. Soil samples were bulked, placed in polyethylene bags, transported on ice to the laboratory, sieved $(<2 \mathrm{~mm})$, and refrigerated at $4^{\circ} \mathrm{C}$.

On the Reedsville Experimental Farm, fenced experimental subplots were established in June on adjacent high- and low-fertility pasture sites and amended with a manure treatment. Each plot was subdivided into quadrants $(1 \mathrm{~m} \times 1 \mathrm{~m})$, which were randomly assigned to receive a manure patch or remain as an untreated control. Manure patches $(25 \mathrm{~cm}$ diameter, $5 \mathrm{~cm}$ height $)$ were fabricated from fresh manure collected from the same fields. Five replicate quadrants from each treatment were sampled at days 0,21 , 40, 63, and 123 after site establishment. On day 0, only the non-manured (control) soils were sampled. Four to five of the samples were used for analysis, depending on the type of analysis. Twelve soil core samples $(15 \mathrm{~cm}$ depth $\times 2.5 \mathrm{~cm}$ diameter) were collected from each quadrant. Core samples were bulked, placed in polyethylene bags, transported on ice to the laboratory, sieved $(<2 \mathrm{~mm})$, and refrigerated at $4^{\circ} \mathrm{C}$.

\subsection{Microbial Biomass Carbon and Potentially Mineralizable} Nitrogen. Microbial biomass carbon was extracted from moist soil ( $80 \%$ water-filled porosity) according to the method of Islam and Weil [32]. Total carbon in soil extracts was measured using a Dohrmann DC-190 TOC analyzer (Rosemount Analytical Inc., Santa Clara, Calif, USA). PMN was determined according to the methods described in Keeney [33]. Ammonia in each sample was measured using a Lachat flow injection analyzer (Hach Company, Loveland, Colo, USA) using the phenolate method.

2.4. Community Level Physiological Profiling. The ability of soil microbial communities to utilize a variety of carbon sources was assessed using community-level physiological profiling originally developed by Garland and Mills [34]. Sterile waring blenders were used to homogenize $(1 \mathrm{~min}$, max speed, $3 \mathrm{x}$ with intermittent cooling on ice) $20 \mathrm{~g}$ of soil in $180 \mathrm{~mL}$ Winogradsky Salts Solution (WSS) [35]. Homogenate was diluted $\left(10^{-3}\right)$ and used to inoculate $\left(100 \mu \mathrm{L} \mathrm{well}^{-1}\right)$ BIOLOG ECO Plate MicroPlates (Biolog Inc., Hayward, Calif, USA). Each plate contained triplicates of 31 individual carbon substrates, plus 3 control wells lacking a carbon source. The microplates were incubated at $25^{\circ} \mathrm{C}$ for five days. Utilization of the carbon source was monitored by measuring absorbance at $590 \mathrm{~nm}$. Readings were taken every 24 hours using an automated plate reader (SpectraMAX 340 pc, Molecular Devices, Sunnyvale, Calif, USA). Absorbance values from the late-log phase of the growth curves (63 hours) were used to calculate diversity indices and principal component as described in Section 2.6. 
2.5. Culture-Dependent Denaturing Gradient Gel Electrophoresis. A detailed description of this procedure is presented in Edenborn and Sexstone [28]. Briefly, twenty grams (dry weight) of composite soil samples from each plot were placed in sterile Waring blenders and shaken for one minute at high speed ( $3 \mathrm{x}$ with intermittent cooling on ice) in $180 \mathrm{~mL}$ of sterile WSS. Blended suspensions were diluted $\left(10^{-2}\right)$ in sterile WSS, and $100 \mu \mathrm{L}$ was plated onto each of four replicate agar plates (final dilution $=10^{-3}$ ) and incubated aerobically for two weeks at $25^{\circ} \mathrm{C}$. Cultured cells were washed sequentially from four replicate R2A plates using WSS $(4 \mathrm{~mL})$ and a sterile disposable inoculating loop. The resulting cell suspensions were vortexed and frozen $\left(-20^{\circ} \mathrm{C}\right)$. DNA was extracted from aliquots of each thawed cell suspension $(1.8 \mathrm{~mL})$ using the MoBio Microbial DNA extraction kit (MoBio Labs, Carlsbad, Calif, USA). The variable V3 region of the 16S rRNA gene from the domain Eubacteria was amplified using the PRBA338F primer with PRUN518R primer as previously described [28]. Composite PCR products $(\sim 150 \mathrm{ng})$ were loaded into a polyacrylamide gel $(8 \%)$ with a $40 \%$ ( $16.8 \mathrm{~g}$ urea; $16 \mathrm{~mL}$ formamide/ $100 \mathrm{~mL}$ ) to $60 \%$ ( $25.2 \mathrm{~g}$ urea; $24 \mathrm{~mL}$ formamide/ $100 \mathrm{~mL}$ ) denaturing gradient and electrophoresed for 14-16 hours at $50 \mathrm{~V}$ and $60^{\circ} \mathrm{C}$ using the DCode Universal Mutation Detection System (BioRad). The gel was visualized by silver staining according to the protocol of Caetano-Anolles and Gresshoff [36]. The developed gel was scanned using Hewlett Packard ScanJet 7400c (Hewlett-Packard Co., Palo Alto, Calif, USA) at a resolution of $600 \mathrm{dpi}$ and saved in uncompressed TIFF format for further analysis.

In pasture soils, temporal changes in CD DGGE fingerprints were determined following application of manure pats to pasture soil treatment plots. Prior to application of manure (day 0), five replicate soil samples were collected from high- and low-fertility plots and the culturable bacterial communities characterized as the manure pats decomposed. Additional samples were collected on days 21, 40, and 63.

2.6. Data Analysis. Differences between MBC organic farm (OF) and pastures (PAS) soils were tested using an analysis of variance (ANOVA) in a $2 \times 3$ factorial design (factor A: high and low input (OF) or high-and low-fertility (PAS); factor B: time-crop combination (OF) or time-manure amendment combination (PAS)). PMN in organic farm soils was compared using a $2 \times 2$ Factorial (Factor A: high-and low-input; Factor B: time-crop combination). For pasture soils, the same factorial design used for $\mathrm{MBC}$ was used for PMN. Tukey's HSD test was used for post-ANOVA pairwise comparisons.

Total well color development (TWCD) for BIOLOG ECO plates was calculated as the sum of absorbance values determined after 63 hours of incubation. Average well color development (AWCD) was calculated from the mean for those 31 absorbance values. Substrate diversity $(H)$ was calculated as $H=-\sum p_{i} \ln \left(p_{i}\right)$, where $p_{i}$ is the proportion of total microbial activity on a particular carbon source. Substrate richness (S) was calculated from the total number of wells with absorbance values greater than 0.25 . Substrate evenness $(E)$ was calculated as $E=H / \ln (S)$. Data were normalized by dividing each substrate absorbance value by the AWCD [34]. Robust principal component analysis (PCA) was done on a covariance matrix of normalized data using alpha $=0$.

DGGE gels were analyzed using Quantity One gel analysis software (BioRad, Hercules, Calif, USA). Analysis of the bands was done by setting background subtraction at 15 using a rolling disk method and generating intensity profiles to evaluate and compare peak size, shape, and location. Bands were picked manually for a limit of intensity greater than 0.05 . Similarity matrices were calculated with Sorensen's index based on the presence/absence of peaks. Analysis of similarity (ANOSIM) was used to determine significant differences between DGGE banding profiles. In ANOSIM, an $R$ value greater than 0 indicates that objects (DGGE profiles) are more dissimilar between groups than within groups, and a $P$ value indicates the level of significance [37]. Enhanced nonmetric multidimensional scaling (NMDS) was used to ordinate DGGE data $[37,38]$. The ability of NMDS to provide a good representation of similarity data in twodimensional space was evaluated based on Kruskal's stress values. Stress values $<0.15$ indicate that the ordination plots presented were useful representations of the CD DGGE data [37].

Multiple and simple correlations analysis was used to assess associations between principal components, NMDS axis scores, MBC, and PMN data. Microbial biomass carbon and PMN were chosen as correlates because they are considered to be broad indicators of soil quality, are relatively easy to measure and interpret, and are linked soil functions such as nutrient cycling, decomposition of organic amendments, physical stabilization of aggregates, soil productivity, and $\mathrm{N}$ supplying potential [39].

Analysis of variance (ANOVA) and correlation analyses were performed using SAS (SAS Institute Inc., Cary, NC). Principle component analysis (PCA), ANOSIM and NMDS were performed using the $R$ package Vegan [40].

\section{Results}

3.1. Microbial Biomass Carbon and Potentially Mineralizable Nitrogen. In the present study, levels of MBC were found to be ten times higher in pasture soils compared with the organic farm (Table 1). In both systems, amendment with manure or compost at different times resulted in significant differences in MBC. Microbial biomass carbon levels in organic farm soils were significantly affected by input $(F=$ 17.57, $P<0.001)$ and the time-crop combination $(F=$ $7.51, P<0.004)$ with no interactions. The MBC in highinput plots (June) varied significantly for all treatments except high-input plots planted with legumes (August) (Table 1). In pastures, MBC was significantly affected by manure amendment and time $(F=17.78, P<0.001)$, but not fertilizer amendment $(F=1.20, P<0.287)$. The interaction was not significant $(F=2.58, P<0.103)$. MBC was significantly higher in September than in May, and the greatest amount of $\mathrm{MBC}$ was found in plots that 
TABLE 1: Microbial biomass carbon (MBC) and potentially mineralizable nitrogen (PMN) in organic farm (OF) and pasture (P) soils ${ }^{\mathrm{a}}$.

\begin{tabular}{|c|c|c|c|c|c|c|c|}
\hline ID & Symbol $^{\mathrm{b}}$ & System & Fertility regime & Crop/amendment & Sampling date & MBC (mg C/kg) & $\mathrm{PMN}(\mathrm{mg} \mathrm{N} / \mathrm{kg})$ \\
\hline $\mathrm{C} 1$ & $\checkmark$ & OF & High Input ${ }^{\mathrm{c}}$ & Tomatoes/peppers & June & $369 \pm 48^{\mathrm{a}}$ & $\mathrm{ND}$ \\
\hline $\mathrm{NC1}$ & $\diamond$ & OF & Low Input ${ }^{\mathrm{d}}$ & Tomatoes/pepper & June & $207 \pm 36^{\mathrm{b}}$ & $\mathrm{ND}$ \\
\hline $\mathrm{C} 2$ & $\diamond$ & OF & High Input & Tomatoes/peppers & Aug & $199 \pm 13^{b}$ & $24 \pm 6^{a}$ \\
\hline CL2 & $\Delta$ & OF & High Input & Legumes & Aug & $282 \pm 29^{\mathrm{ab}}$ & $31 \pm 4^{\mathrm{a}}$ \\
\hline $\mathrm{NC} 2$ & $\diamond$ & OF & Low Input & Tomatoes/peppers & Aug & $156 \pm 13^{\mathrm{b}}$ & $18 \pm 4^{\mathrm{a}}$ \\
\hline NCL2 & $\triangle$ & OF & Low Input & Legumes & Aug & $195 \pm 12^{\mathrm{b}}$ & $19 \pm 2^{\mathrm{a}}$ \\
\hline $\mathrm{H} 1$ & $\square$ & $\mathrm{P}$ & High fertility ${ }^{\mathrm{e}}$ & None & May & $1659 \pm 133^{c}$ & $110 \pm 18^{\mathrm{abc}}$ \\
\hline L1 & $\square$ & $\mathrm{P}$ & Low fertility ${ }^{\mathrm{f}}$ & None & May & $1931 \pm 79^{b c}$ & $121 \pm 11^{\mathrm{ab}}$ \\
\hline $\mathrm{H} 2$ & $\square$ & $\mathrm{P}$ & High fertility & None & Sept & $1915 \pm 126^{\mathrm{bc}}$ & $59 \pm 8^{c}$ \\
\hline HM2 & - & $\mathrm{P}$ & High fertility & Manure & Sept & $2666 \pm 126^{\mathrm{a}}$ & $125 \pm 10^{\mathrm{ab}}$ \\
\hline $\mathrm{L} 2$ & $\square$ & $\mathrm{P}$ & Low fertility ${ }^{c}$ & None & Sept & $2214 \pm 79^{\mathrm{abc}}$ & $85 \pm 11^{\mathrm{bc}}$ \\
\hline LM2 & $\circ$ & $\mathrm{P}$ & Low fertility & Manure & Sept & $2443 \pm 196^{\mathrm{ab}}$ & $142 \pm 13^{\mathrm{a}}$ \\
\hline $\begin{array}{l}\text { Average } \\
\text { organic } \\
\text { farm }\end{array}$ & & & & & & $235 \pm 77$ & $23 \pm 6$ \\
\hline $\begin{array}{l}\text { Average } \\
\text { pasture }\end{array}$ & & & & & & $2138 \pm 374$ & $107 \pm 30$ \\
\hline $\begin{array}{l}\text { Mean valu } \\
\text { Symbols u } \\
\text { High inpu } \\
{ }^{1} \text { Low inpu } \\
\text { High ferti } \\
\text { Low fertili }\end{array}$ & $\begin{array}{l}=4( \pm \text { SEI } \\
\mathrm{n} \text { figures th } \\
0-20 \text { tons } \mathrm{c} \\
\text { een manur } \\
\text { inorganic } \\
\text { inorganic } \mathrm{f}\end{array}$ & $\begin{array}{l}\text { llowed b } \\
\text { ghout pa } \\
\text { veight/ac } \\
\text { ye + vetcl } \\
\text { lizer, P, 1 } \\
\text { zer, P, 67 }\end{array}$ & $\begin{array}{l}\text { e same letter are } \mathrm{n} \\
\text { composted dairy } \\
\text { led into soil } 7-10 \\
\mathrm{~g} / \mathrm{ha} \text { and } \mathrm{K}, 390 \mathrm{~kg} \\
\text { ha and } \mathrm{K}, 195 \mathrm{~kg} / \mathrm{h}\end{array}$ & $\begin{array}{l}\text { gnificantly different } \\
\text { nure + green manure } \\
\text { prior to planting. }\end{array}$ & $\begin{array}{l}0.05 \text { ) as determi } \\
+ \text { vetch) appliec }\end{array}$ & $\begin{array}{l}\text { y Tukey's studentiz } \\
\text { tilled into soil 7-10 }\end{array}$ & $\begin{array}{l}\text { inge (HSD) test. } \\
\text { prior to planting. }\end{array}$ \\
\hline
\end{tabular}

had been amended with manure (Table 1). Clear statistical differences between inorganic fertilizer applications were not demonstrated; however, lower levels of MBC generally were observed in low- compared with high-fertility plots, both in May and September.

Pasture soils on average contained four times more PMN than organic farm soils (Table 1). In organic farm soils, a significant difference in PMN was found due to input ( $F=4.87, P<0.048)$, but neither time-crop combination $(F=0.99, P<0.339)$ nor the interaction of these two factors was significant $(F=0.757, P<0.402)$. When individual means were compared, no differences were found in PMN between different organic farm soils (Table 1). In pastures, both fertilizer input $(F=4.93, P<0.040)$ and timemanure amendment $(F=7.43, P<0.004)$ were found to have a significant effect on PMN without any interaction $(F=0.203, P<0.979)$. Potentially mineralizable nitrogen was significantly higher in the plots with manure compared to fertilizer input (Table 1).

3.2. Community Level Physiological Profiling. Shannon diversity indices ranged between $3.26-3.35$ and $3.27-3.29$; richness values ranged between $28-30$ and 28-29; evenness between $0.975-0.982$, and $0.975-0.977$ for the organic farm and pasture soils, respectively. There were no significant differences $(P>0.05)$ in functional diversity indices based on soil type or agronomic treatment.

Ordination of the CLPP data using principal component analysis clearly distinguished low-input organic farm soils from other soils. We first performed PCA on all 31 substrates

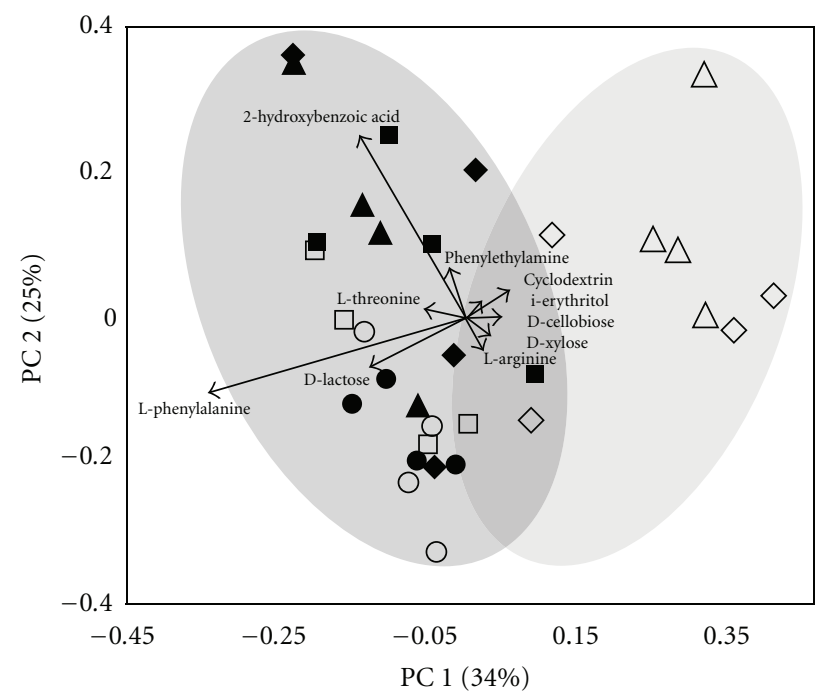

FIGURE 1: Ordination biplots of principal components (PC1 and PC2) from CLPP analysis of organic farm and pasture soils subjected to varying fertility regimes and crop rotations from August and September. Symbol designations are as described in Table 1.

to identify the most strongly loaded, noncollinear substrates. Ten of these substrates were then used for a subsequent PCA [41]. These substrates were L-arginine, D-cellobiose, cyclodextrin, i-erythritol, 2-hydroybenzoic acid, D-lactose, L-phenylalanine, phenylethylamine, L-threonine, and Dxylose. Ordination of these data is presented in Figure 1 
where the distinct cluster formed by low-input organic farm soils can be visualized. In this analysis, $75 \%$ of the variance was accounted for by the first three principal components. The first principal component was most strongly correlated with the utilization of L-phenylalanine $(-0.94)$, D-lactose $(-0.68)$, and L-threonine $(-0.61)$. Principal component 2 was most strongly correlated with 2-hydroxybenzoic acid (0.87), and principal component 3 was most strongly correlated with phenylethylamine (0.95) and L-arginine (0.69).

3.3. Culture-Dependent Denaturing Gradient Gel Electrophoresis. CD DGGE profiles of $16 \mathrm{~S}$ rDNA showed clear differences between culturable bacterial communities in organic farm and pasture soils (Figure 2(a)). Culturable bacterial communities in the two soil types were highly distinct (ANOSIMS; $R=1.00, P<0.023$ ). Ordination of the data using NMDS demonstrated that legume cropping (OF) and fertilizer (PAS) had more impact on the structure of culturable soil bacterial communities than organic matter amendments (compost or manure) (Figure 2(b)).

At each sampling time, PCR products from three replicate plots per treatment were combined to create a composite profile. Significant differences were found between the highand low-fertility plots on day 0 (ANOSIMS; $R=0.36$, $P<0.018$ ). Nonmetric multidimensional scaling analysis of these data is presented in Figure 3(a). There were significant differences in bacterial communities over time (ANOSIMS; $R=0.36, P<0.013)$, but no significant differences were observed due to treatment $(R=-0.162, P<0.835)$. Ordination of the data also revealed distinct clustering based on sampling time (Figure 3(b)).

In June and August, soils collected from three replicate plots per treatment at the organic farm were used for CD DGGE analysis. There were no significant differences in CD DGGE profiles from different treatments in June (ANOSIMS; $R=0.44, P<0.087$ ); however, significant differences were observed in August $(R=0.454, P<0.006)$. Bacterial communities from tomato and pepper plots (high and low fertility) collected in both June and August clustered together (Figure 4(a)). In contrast, the communities from soils that had been planted with legumes clustered separately from those from soils planted with tomatoes and peppers and from each other (Figure 4(b)). Kruskal's stress values for all analyses were $<0.15$.

3.4. Correlations between $M B C, P M N, C L P P$, and CD DGGE. Multiple correlation analysis was used to explore potential relationships between the principal component scores from the PCA analysis of CLPP data (Figure 1) and other measured variables. Significant correlations were observed between the CLPP principal components, MBC $(R=0.71, P<0.001)$ and PMN $(R=0.47, P<0.007)$. When organic farm and pasture sample were analyzed separately, the correlations improved $(R>0.85, P<0.001)$ for $\mathrm{MBC}$ and $\mathrm{PMN}$ from both systems. Multiple correlations between the CLPP principal components (Figure 1) and the axis scores from NMDS of CD DGGE data from the organic farm samples in
August 2004 (Figure 4(b)) also were highly significant (dimension 1: $R=0.99, P<0.001$; dimension $2: R=0.98, P<$ $0.001)$. Multiple correlation analysis was not performed on pasture data because samples for CD DGGE and CLPP were collected on different sampling dates. Simple correlations were performed for both agronomic systems using axis scores from NMDS of CD DGGE data and the MBC and PMN data. In both soil systems, significant correlations were found between the DGGE axis scores and MBC (Figure 5) but not between DGGE axis scores and PMN (data not shown).

\section{Discussion}

Ideal soil quality indicators are those that reflect ecosystem processes and integrate physical, chemical, and biological properties of soil. They are also sensitive to environmental disturbances and are practical and economical for a widevariety of users [42]. Microbial community structure is of potential use as an indicator of soil quality [3]; however, the linkage to ecosystem processes and soil status is not always evident in ways that can be easily integrated into predictive models [43]. Exploring the composition of microbial communities in soil often depends on computation and inspection of derived parameters from multivariate models and the construction of ordination plots. This approach often does not provide easily interpretable indices for the quantification and comparison of soil microbial diversity. Therefore, we attempted to correlate derived parameters from multivariate analyses with more straightforward measures of soil change and determined if profiles of culturable soil bacterial communities provide information about shortterm changes in soil quality that are not characterized using conventional microbial soil quality indicators.

The organic farm and the perennial pasture represent contrasting research plots that have received regular soil amendments and plant management over the past decade. Long-term changes in soil properties suggest an overall improvement in the soil quality at both sites [30, 31, 44]; however, short-term effects of specific agronomic treatments have been more difficult to resolve. In this study, we explored the responsiveness of culturable soil bacterial communities to soil management and their potential relationship to more commonly employed measures of soil perturbation (MBC, PMN, and CLPP). Culturable bacteria were sensitive and early indicators of change in metal-contaminated environments [27, 45].

We tested the hypothesis that fast-growing culturable bacterial communities, as reflected by CD DGGE profiles, are sensitive to short-term changes in dynamic agronomic systems and that these responses can be linked to other microbial measures of soil status. Obvious differences were observed between CD DGGE fingerprints of 16S rRNA genes from the two soil types. However, CD DGGE profiles were not uniformly sensitive to within-site treatment differences. Rather, we found that CD DGGE measured differences in soils that were amended with inorganic fertilizers and/or cropped with legumes, while MBC, PMN, and CLPP were more responsive to additions of manure and compost 


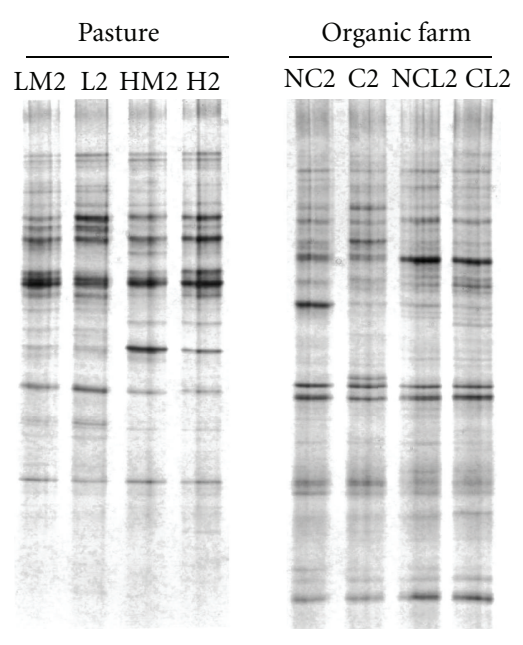

(a)

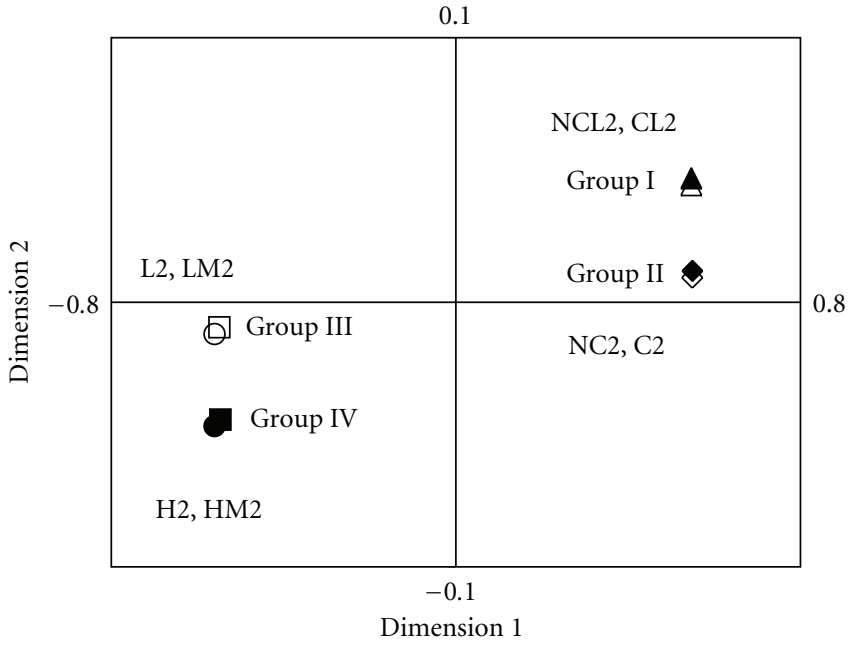

(b)

FIGURE 2: (a) DGGE gel of pooled PCR-amplified 16S rRNA genes from culture-dependent bacterial communities of organic farm and pasture from August to September 2004 and (b) ordination plots of dimensions 1 and 2 from NMDS analysis of CD DGGE data. Stress of the plot $=0.000053$. Symbol designations are as described in Table 1 .

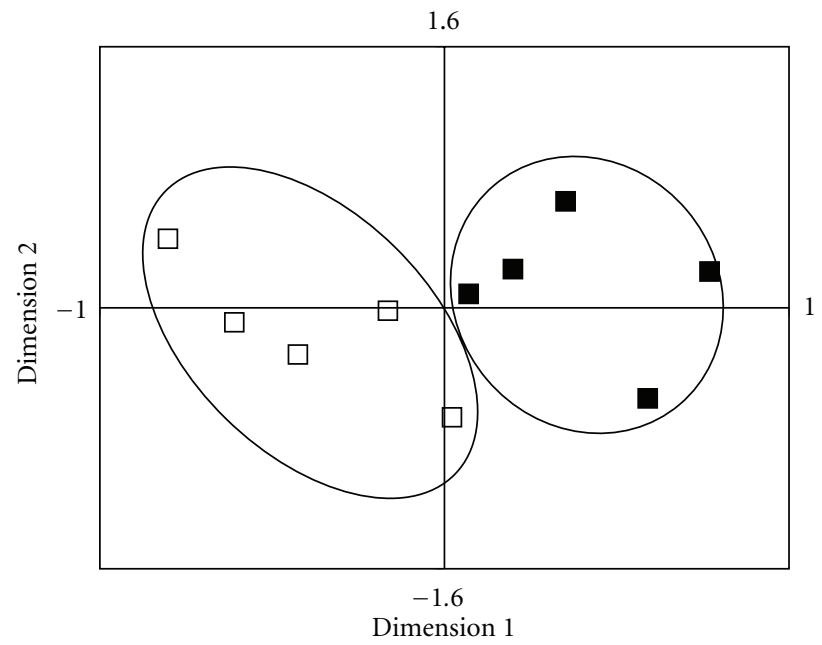

(a)

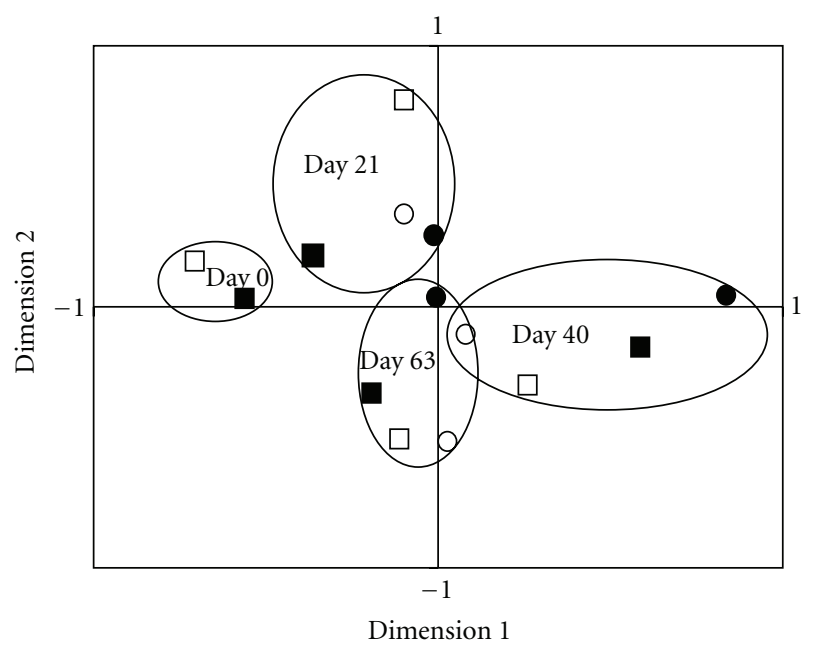

(b)

FIGURE 3: Ordination plots of DGGE data from pasture soils in (a) May and (b) May-September. Stress of the plot = (a) 0.15 and (b) 0.15. Symbol designations are as described in Table 1.

to soils. It is quite possible that the fertilizer effect we observed in pasture soils also involved a legume effect. For the past decade, experimental pastures at Reedsville, WVa, have been subjected to equal grazing pressure and animal waste deposition but have received two different levels of phosphorus, potassium, and lime amendments [44]. The higher phosphorous treatment has been shown to favor the persistence of pasture legumes, such as red and white clover, in these soils [46]. Girvan et al. [17] hypothesized that soil type and legume cropping were the overriding factors controlling the structure of bacterial communities in agricultural soils. Additional studies support the observation that legumes and nitrogen availability can influence bacterial community $[47,48]$. Conventional fertilization with inorganic phosphates also has been shown to increase the diversity and activity of free-living nitrogen-fixing bacteria compared with organic amendments [49].

We found positive correlations between CLPP principal component scores and MBC and NMDS axis scores and $\mathrm{MBC}$ in both systems. Previous studies also have identified correlations between the structure and function of culturable microbial communities and physicochemical and 


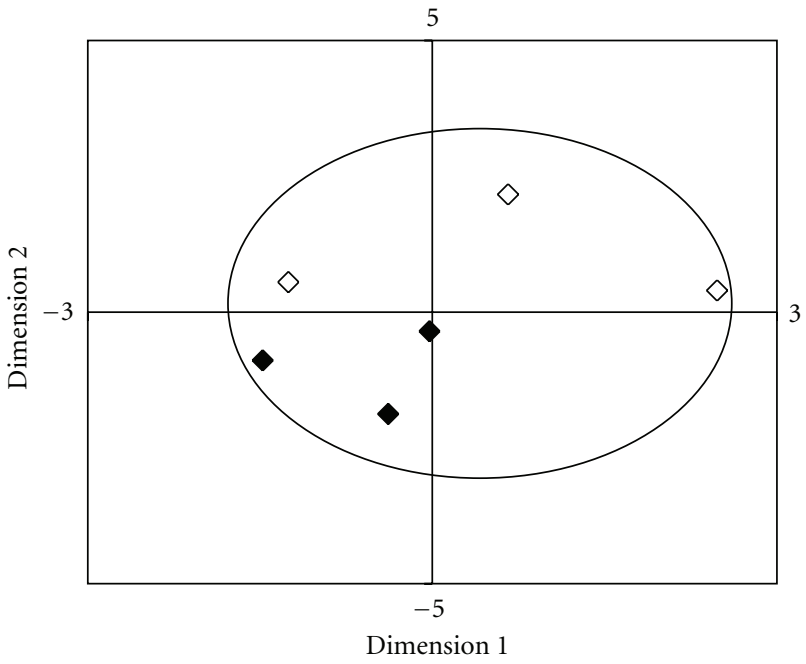

(a)

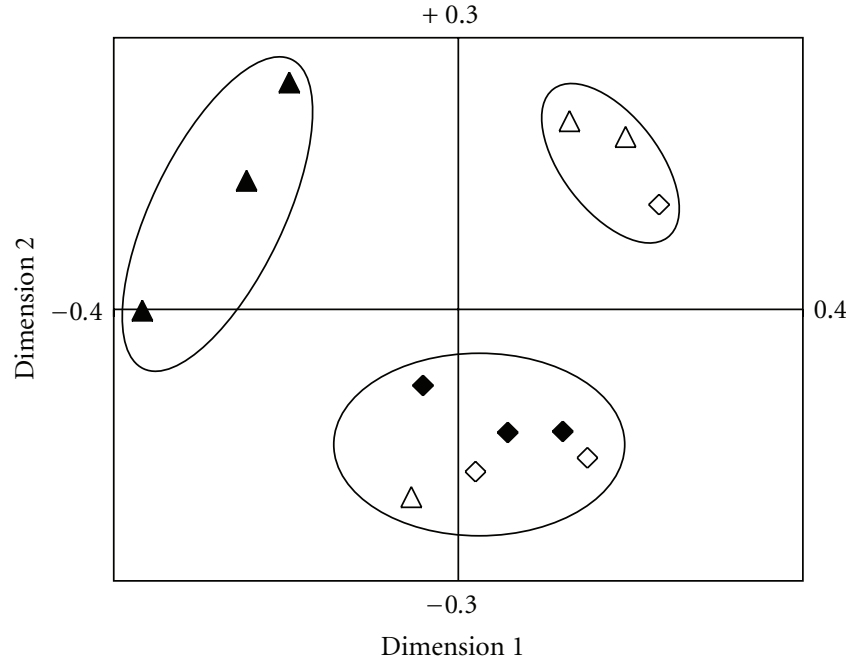

(b)

FIGURE 4: Ordination plots DGGE data from organic farm market garden soils in (a) June and (b) August. Stress of the plot $=(\mathrm{a}) 0.013$ and (b) 0.13. Symbol designations are as described in Table 1.

vegetative parameters [45], CLPP data, gross $\mathrm{N}$ flux, and soil respiration [50-52] and organic matter content, $\mathrm{pH}$, and sodium [53]. Although correlation does not imply causation, correlative relationships suggest that these variables respond in a similar manner to environmental disturbances [50] and provide the foundation to explore potential mechanisms that may link structure and function. For example, CLPP employs microbial growth on potentially important carbon substrates, and we observed significant correlations between the CD DGGE and CLPP. Exploration of the CLPP data using PCA analysis suggested that bacteria using aromatic substrates such as L-phenylalanine and 2hydroxybenzoic may represent useful physiological groups to further explore using CD DGGE. Langenheder et al. [54] have suggested that bacterial community structure may be related to narrow functions such as degradation of semilabile carbon compounds rather than to broad functions such as respiration and biomass production. If this is accurate, then characterizing culturable bacterial communities with specific physiological capabilities or narrow niche preferences may improve our ability to distinguish between soils that have been impacted by anthropogenic perturbations. Recently, Ritz [55] has argued that culturable communities have no utility in contemporary microbial ecology and cannot be related to soil fertility. Our results do not support this conclusion. Rather, we agree with Nichols [56] that microbial cultivation is a re-emerging frontier that can provide information not directly observable from culture-independent and sequencing efforts alone. Although bacterial growth on different types of solid media is inherently selective, the ability to partition complex soil bacterial communities into definable physiological subsets using a variety of isolation media and incubation conditions should be viewed as a potential strength of the CD DGGE technique, since selected physiological groups may be most sensitive and responsive to environmental change. It is insufficient to merely catalog genes to understand how environmental factors govern shifts in community structure. Natural selection acts on phenotype, and physiological characteristics are often linked to more than one gene and are regulated by multiple external factors. Classifying microorganisms into meaningful functional groups and characterizing the physiological and ecological redundancies within these groups potentially can make community data more manageable and relevant [43].

\section{Conclusions}

The organic farm and pasture represent systems with contrasting soil types, land use, and fertility regimes. In this study, we used MBC, PMN, CLPP, and CD DGGE of the 16S rRNA gene to compare microbial communities as a function of agronomic amendments. There were significant correlations between MBC and PMN and variables derived from analysis of the functional and genetic diversity of soil communities; however, each measurement technique exhibited a different response to the fertility amendments. Overall, MBC, PMN, and CLPP were most responsive to additions of manure and compost to soils; however, only CD DGGE revealed clear differences in soils that were amended with inorganic fertilizers and/or cropped with legumes. Therefore, different measures of microbial community structure do not provide redundant information in soil quality analysis, and culturable bacterial communities can provide useful indicators of select agronomic perturbations.

The minority status of culturable bacteria does not preclude the possibility that these communities are useful to advance our understanding of how microbial communities are linked to environmental processes. Culture-based techniques such CD DGGE and CLPP have the potential to provide critical insight into the mechanisms that link structural and functional diversity, to explore ways to assess 


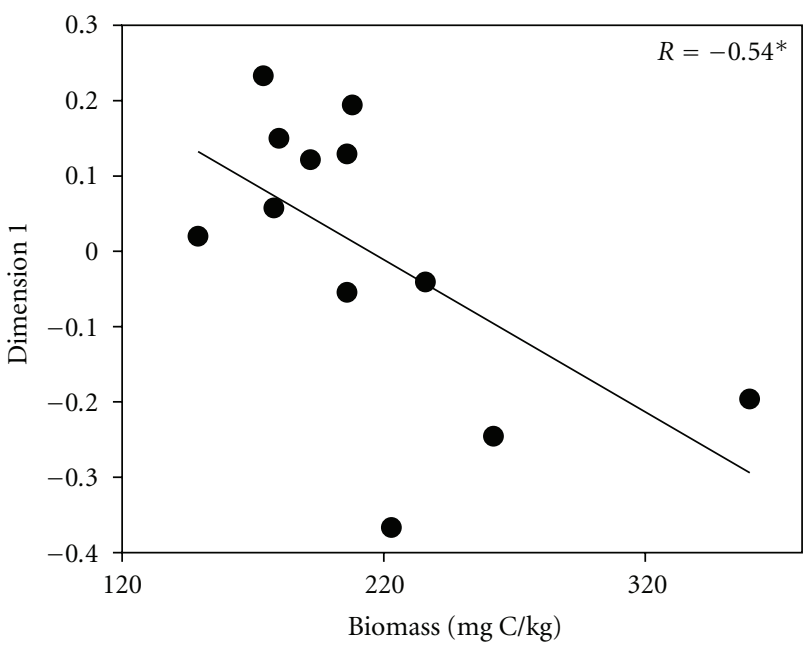

(a)

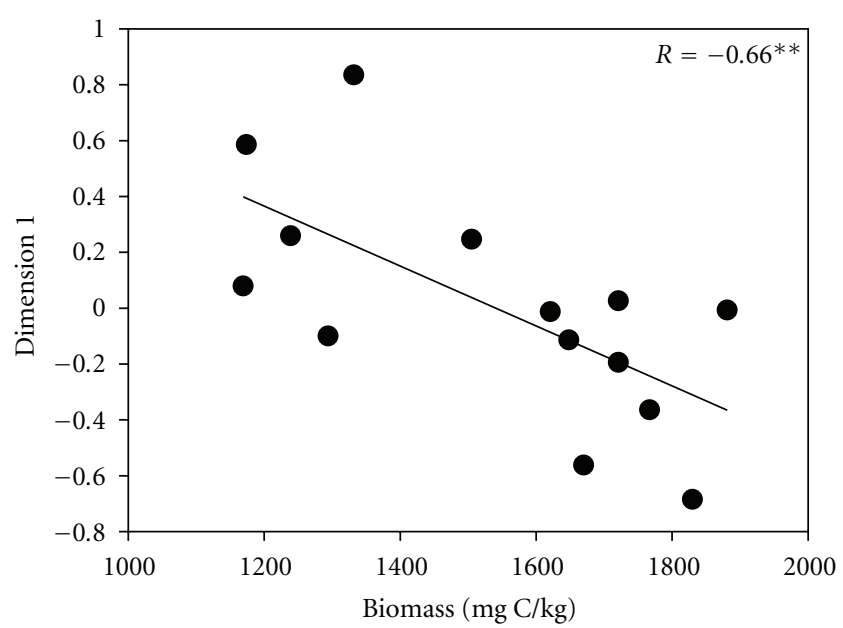

(c)

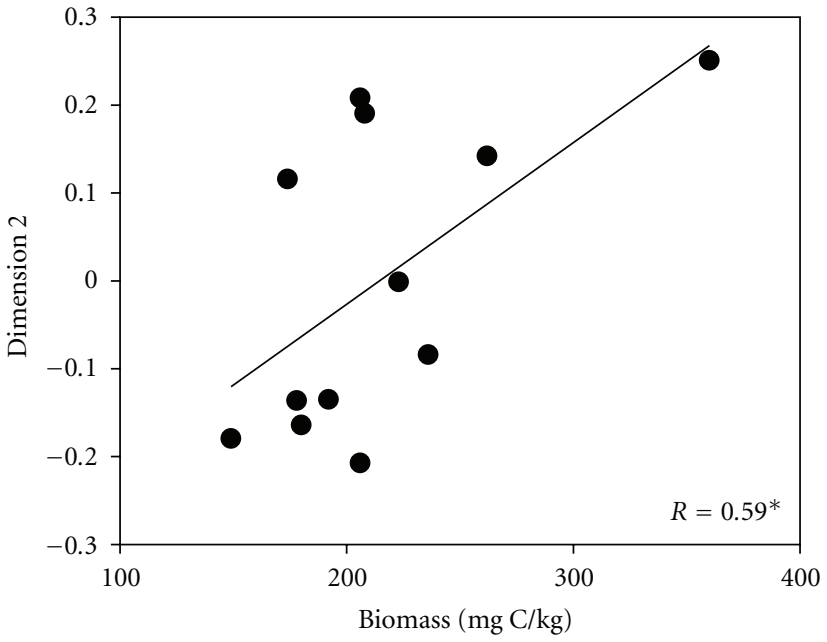

(b)

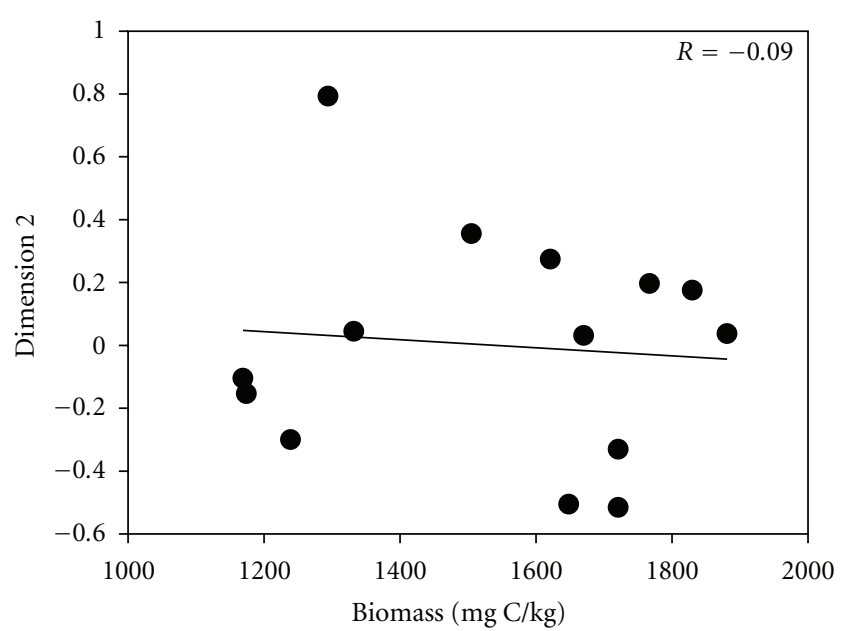

(d)

FIGURE 5: Scatter plots, trendlines, and Pearson correlation coefficients between MBC and dimensions 1 and 2 from NMDS analysis of CD DDGE profiles from organic farm in August ( $a, b)$ and pasture days 0, 21, 40, and 63 between May and September (c, d). Significant correlations are indicated by ${ }^{* *} P<0.01$ and ${ }^{*} P<0.05$.

physiological and ecological redundancies within functional groups, and to advance our understanding of how microbial diversity contributes to soil quality.

\section{Acknowledgments}

The authors thank Dr. George Seidel for assistance with statistical analyses. This work was supported by grants from USDA and by the West Virginia University Davis College of Agriculture, Forestry, and Consumer Sciences through funding appropriated under the Hatch Act.

\section{References}

[1] A. C. Kennedy and R. I. Papendick, "Microbial characteristics of soil quality," Journal of Soil \& Water Conservation, vol. 50, no. 3, pp. 243-248, 1995.
[2] H. Y. Sun, S. P. Deng, and W. R. Raun, "Bacterial community structure and diversity in a century-old manure-treated agroecosystem," Applied and Environmental Microbiology, vol. 70, no. 10, pp. 5868-5874, 2004.

[3] B. Stenberg, "Monitoring soil quality of arable land: microbiological indicators," Acta Agriculturae Scandinavica, vol. 49, no. 1, pp. 1-24, 1999.

[4] A. M. Ibekwe, A. C. Kennedy, P. S. Frohne, S. K. Papiernik, C. H. Yang, and D. E. Crowley, "Microbial diversity along a transect of agronomic zones," FEMS Microbiology Ecology, vol. 39, no. 3, pp. 183-191, 2002.

[5] P. Templer, S. Findlay, and G. Lovett, "Soil microbial biomass and nitrogen transformations among five tree species of the Catskill Mountains, New York, USA," Soil Biology and Biochemistry, vol. 35, no. 4, pp. 607-613, 2003.

[6] M. Schloter, O. Dilly, and J. C. Munch, "Indicators for evaluating soil quality," Agriculture, Ecosystems and Environment, vol. 98, no. 1-3, pp. 255-262, 2003. 
[7] K. Smalla, U. Wachtendorf, H. Heuer, W. T. Liu, and L. Forney, "Analysis of BIOLOG GN substrate utilization patterns by microbial communities," Applied and Environmental Microbiology, vol. 64, no. 4, pp. 1220-1225, 1998.

[8] J. L. Garland, "Potential and limitations of BIOLOG for microbial community analysis," in Proceedings of the 8th International Symposium on Microbial Ecology Atlantic Canada Society for Microbial Ecology, C. R. Bell, M. Brylinsky, and P. Johnson-Green, Eds., pp. 1-7, Society for Microbial Ecology, Halifax, NS, Canada, 1999.

[9] A. Konopka, L. Oliver, and R. F. Turco, "The use of carbon substrate utilization patterns in environmental and ecological microbiology," Microbial Ecology, vol. 35, no. 2, pp. 103-115, 1998.

[10] J. Preston-Mafham, L. Boddy, and P. F. Randerson, "Analysis of microbial community functional diversity using sole-carbonsource utilisation profiles-a critique," FEMS Microbiology Ecology, vol. 42, no. 1, pp. 1-14, 2002.

[11] S. Sharma, A. Rangger, and H. Insam, "Effects of decomposing maize litter on community level physiological profiles of soil bacteria," Microbial Ecology, vol. 35, no. 3, pp. 301-310, 1998.

[12] G. D. Bending, C. Putland, and F. Rayns, "Changes in microbial community metabolism and labile organic matter fractions as early indicators of the impact of management on soil biological quality," Biology and Fertility of Soils, vol. 31, no. 1, pp. 78-84, 2000.

[13] B. Williams, S. Grayston, and E. Reid, "Influence of synthetic sheep urine on the microbial biomass, activity and community structure in two pastures in the Scottish uplands," Plant and Soil, vol. 225, no. 1-2, pp. 175-185, 2000.

[14] R. Miethling, G. Wieland, H. Backhaus, and C. C. Tebbe, "Variation of microbial rhizosphere communities in response to crop species, soil origin, and inoculation with Sinorhizobium meliloti L33," Microbial Ecology, vol. 40, no. 1, pp. 43-56, 2000.

[15] F. Widmer, A. Fließbach, E. Laczkó, J. Schulze-Aurich, and J. Zeyer, "Assessing soil biological characteristics: a comparison of bulk soil community DNA-, PLFA-, and biolog analyses," Soil Biology and Biochemistry, vol. 33, no. 7-8, pp. 1029-1036, 2001.

[16] G. D. Bending, M. K. Turner, and J. E. Jones, "Interactions between crop residue and soil organic matter quality and the functional diversity of soil microbial communities," Soil Biology and Biochemistry, vol. 34, no. 8, pp. 1073-1082, 2002.

[17] M. S. Girvan, J. Bullimore, J. N. Pretty, A. M. Osborn, and A. S. Ball, "Soil type is the primary determinant of the composition of the total and active bacterial communities in arable soils," Applied and Environmental Microbiology, vol. 69, no. 3, pp. 1800-1809, 2003.

[18] E. Malosso, L. English, D. W. Hopkins, and A. G. O’Donnell, "Community level physiological profile response to plant residue additions in Antarctic soils," Biology and Fertility of Soils, vol. 42, no. 1, pp. 60-65, 2005.

[19] C. H. Nakatsu, "Soil microbial community analysis using denaturing gradient gel electrophoresis," Soil Science Society of America Journal, vol. 71, no. 2, pp. 562-571, 2007.

[20] J. E. Thies, "Soil microbial community analysis using terminal restriction fragment length polymorphisms," Soil Science Society of America Journal, vol. 71, no. 2, pp. 579-591, 2007.

[21] G. Muyzer and K. Smalla, "Application of denaturing gradient gel electrophoresis (DGGE) and temperature gradient gel electrophoresis (TGGE) in microbial ecology," Antonie van Leeuwenhoek, vol. 73, no. 1, pp. 127-141, 1998.
[22] S. J. Bent, J. D. Pierson, L. J. Forney et al., "Measuring species richness based on microbial community fingerprints: the emperor has no clothes," Applied and Environmental Microbiology, vol. 73, no. 7, pp. 2399-2401, 2007.

[23] R. I. Amann, "Fluorescently labeled, ribosomal RNA-targeted oligonucleotide probes in the study of microbial ecology," Molecular Ecology, vol. 4, pp. 543-553, 1995.

[24] P. Hugenholtz, B. M. Goebel, and N. R. Pace, "Impact of culture-independent studies on the emerging phylogenetic view of bacterial diversity," Journal of Bacteriology, vol. 180, no. 18, pp. 4765-4774, 1998.

[25] L. Øvreås and V. Torsvik, "Microbial diversity and community structure in two different agricultural soil communities," Microbial Ecology, vol. 36, no. 3, pp. 303-315, 1998.

[26] S. M. Barns, S. L. Takala, and C. R. Kuske, "Wide distribution and diversity of members of the bacterial kingdom Acidobacterium in the environment," Applied and Environmental Microbiology, vol. 65, no. 4, pp. 1731-1737, 1999.

[27] R. J. Ellis, P. Morgan, A. J. Weightman, and J. C. Fry, "Cultivation-dependent and -independent approaches for determining bacterial diversity in heavy-metal-contaminated soil," Applied and Environmental Microbiology, vol. 69, no. 6, pp. 3223-3230, 2003.

[28] S. L. Edenborn and A. J. Sexstone, "DGGE fingerprinting of culturable soil bacterial communities complements cultureindependent analyses," Soil Biology and Biochemistry, vol. 39, no. 7, pp. 1570-1579, 2007.

[29] Soil Survey Staff, Soil Taxonomy, A Basic System of Soil Classification for Making and Interpreting Soil Surveys, Agricultural Handbook Number 436, Natural Resources Conservation Service, Washington, DC, USA, 2nd edition, 1999.

[30] T. B. Childers, The effects of low and high fertility treatments on soil quality, yields, pest incidence and labor requirements of a post-translational organic market garden system, M.S. thesis, West Virginia University, Morgantown, WVa, USA, 2005.

[31] Y. Sutanto, Manure from grazing cattle: effects on soil microbial communities and soil quality in northern West Virginia pastures, M.S. thesis, West Virginia University, Morgantown, WVa, USA, 2005.

[32] K. R. Islam and R. R. Weil, "Microwave irradiation of soil for routine measurement of microbial biomass carbon," Biology and Fertility of Soils, vol. 27, no. 4, pp. 408-416, 1998.

[33] D. Keeney, "Nitrogen-availability indices," in Methods of Soil Analysis, Part 2-Chemical and Microbiological Properties, A. L. Page, R. H. Miller, and D. R. Keeney, Eds., pp. 711-733, American Society of Agronomy, Madison, Wis, USA, 2nd edition, 1982.

[34] J. L. Garland and A. L. Mills, "Classification and characterization of heterotrophic microbial communities on the basis of patterns of community-level sole-carbon-source utilization," Applied and Environmental Microbiology, vol. 57, no. 8, pp. 2351-2359, 1991.

[35] D. A. Zuberer, "Recovery and enumeration of viable bacteria," in Methods of Soil Analysis, Part 2. Microbiological and Biochemical Properties, R.W. Weaver, Ed., pp. 119-144, Soil Science Society of America, Madison, Wis, USA, 1994.

[36] G. Caetano-Anolles and P. M. Gresshoff, "Staining nucleic acids with silver: an alternative to radioisotopic and fluorescent labeling," Promega Notes Magazine, vol. 45, pp. 13-18, 1994.

[37] G. Rees, D. Baldwin, B. Watson, S. Perryman, and D. Nielsen, "Ordination and significance testing of microbial community composition derived from terminal restriction fragment 
length polymorphisms: application of multivariate statistics," Antonie van Leeuwenhoek, vol. 86, no. 4, pp. 339-347, 2004.

[38] N. Fromin, J. Hamelin, S. Tarnawski et al., "Statistical analysis of denaturing gel electrophoresis (DGGE) fingerprinting patterns," Environmental Microbiology, vol. 4, no. 11, pp. 634 643, 2002.

[39] J. D. Knoepp, D. C. Coleman, D. A. Crossley Jr., and J. S. Clark, "Biological indices of soil quality: an ecosystem case study of their use," Forest Ecology and Management, vol. 138, no. 1-3, pp. 357-368, 2000.

[40] J. Oksanen, R. Kindt, P. Legendre, and B. O’Hara, "Vegan: community ecology package," $\mathrm{R}$ package version 1.8-5, 2007 http://cran.r-project.org/.

[41] F. B. Bryant and P. R. Yarnold, "Principal-components analysis and exploratory and confirmatory factor analysis," in Reading and Understanding Multivariate Statistics, L. G. Grimm and P. R. Yarnold, Eds., pp. 99-136, American Psychological Association, Washington, DC, USA, 1995.

[42] J. W. Doran and T. B. Parkin, "Quantitative indicators of soil quality: a minimum data set," in Methods for Assessing Soil Quality, J. W. Doran and A. J. Jones, Eds., pp. 25-37, Soil Science Society of America, Madison, Wis, USA, 1996.

[43] S. D. Allison and J. B. H. Martiny, "Resistance, resilience, and redundancy in microbial communities," Proceedings of the National Academy of Sciences of the United States of America, vol. 105, no. 1, pp. 11512-11519, 2008.

[44] E. C. Prigge, W. B. Bryan, and E. S. Goldman-Innis, "Earlyand late-season grazing of orchardgrass and fescue hayfields overseeded with red clover," Agronomy Journal, vol. 91, no. 4, pp. 690-696, 1999.

[45] C. B. Zhang, L. N. Huang, W. S. Shu, J. W. Qiu, J. T. Zhang, and C. Y. Lan, "Structural and functional diversity of a culturable bacterial community during the early stages of revegetation near a $\mathrm{Pb} / \mathrm{Zn}$ smelter in Guangdong, PR China," Ecological Engineering, vol. 30, no. 1, pp. 16-26, 2007.

[46] W. B. Bryan, T. A. Mills, and F. X. Rosica, "Effects of grazing management and soil amendments on hill land pasture botanical composition," Applied Agricultural Research, vol. 1, pp. 279-302, 1987.

[47] N. Kennedy, E. Brodie, J. Connolly, and N. Clipson, "Impact of lime, nitrogen and plant species on bacterial community structure in grassland microcosms," Environmental Microbiology, vol. 6, no. 10, pp. 1070-1080, 2004.

[48] H. Chu, T. Fujii, T. Morimoto et al., "Community structure of ammonia-oxidizing bacteria under long-term application of mineral fertilizer and organic manure in a sandy loam soil," Applied and Environmental Microbiology, vol. 73, no. 2, pp. 485-491, 2007.

[49] C. H. Orr, A. James, C. Leifert, J. M. Cooper, and S. P. Cummings, "Diversity and activity of free-living nitrogenfixing bacteria and total bacteria in organic and conventionally managed soils," Applied and Environmental Microbiology, vol. 77, no. 3, pp. 911-919, 2011.

[50] W. R. Cookson, M. Osman, P. Marschner et al., "Controls on soil nitrogen cycling and microbial community composition across land use and incubation temperature," Soil Biology and Biochemistry, vol. 39, no. 3, pp. 744-756, 2007.

[51] L. Kerkhof, M. Santoro, and J. Garland, "Response of soybean rhizosphere communities to human hygiene water addition as determined by community level physiological profiling (CLPP) and terminal restriction fragment length polymorphism (TRFLP) analysis," FEMS Microbiology Letters, vol. 184, no. 1, pp. 95-101, 2000.
[52] E. Brodie, S. Edwards, and N. Clipson, "Bacterial community dynamics across a floristic gradient in a temperate upland grassland ecosystem," Microbial Ecology, vol. 44, no. 3, pp. 260-270, 2002.

[53] S. J. Grayston, C. D. Campbell, R. D. Bardgett et al., "Assessing shifts in microbial community structure across a range of grasslands of differing management intensity using CLPP, PLFA and community DNA techniques," Applied Soil Ecology, vol. 25, no. 1, pp. 63-84, 2004.

[54] S. Langenheder, E. S. Lindstrom, and L. J. Tranvik, "Structure and function of bacterial communities emerging from different sources under identical conditions," Applied and Environmental Microbiology, vol. 72, no. 1, pp. 212-220, 2006.

[55] K. Ritz, "The plate debate: cultivable communities have no utility in contemporary environmental microbial ecology," FEMS Microbiology Ecology, vol. 60, no. 3, pp. 358-362, 2007.

[56] D. Nichols, "Cultivation gives context to the microbial ecologist," FEMS Microbiology Ecology, vol. 60, no. 3, pp. 351-357, 2007. 

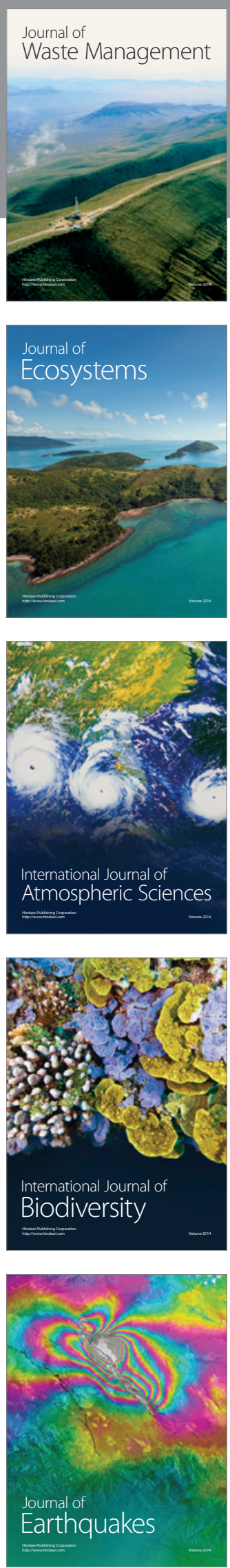
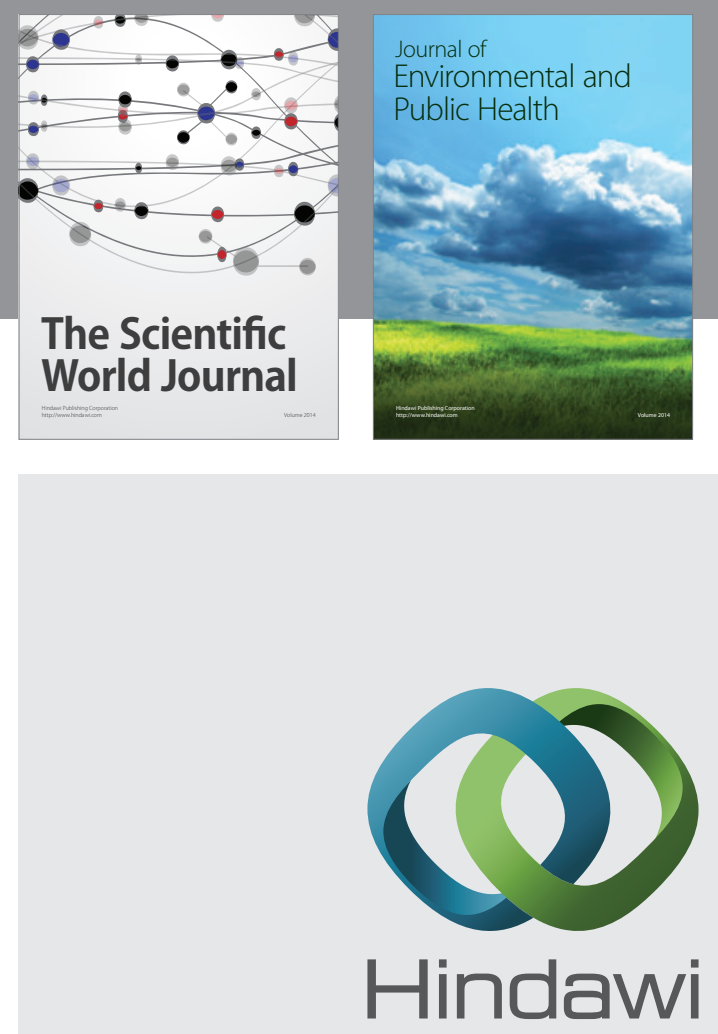

Submit your manuscripts at

http://www.hindawi.com
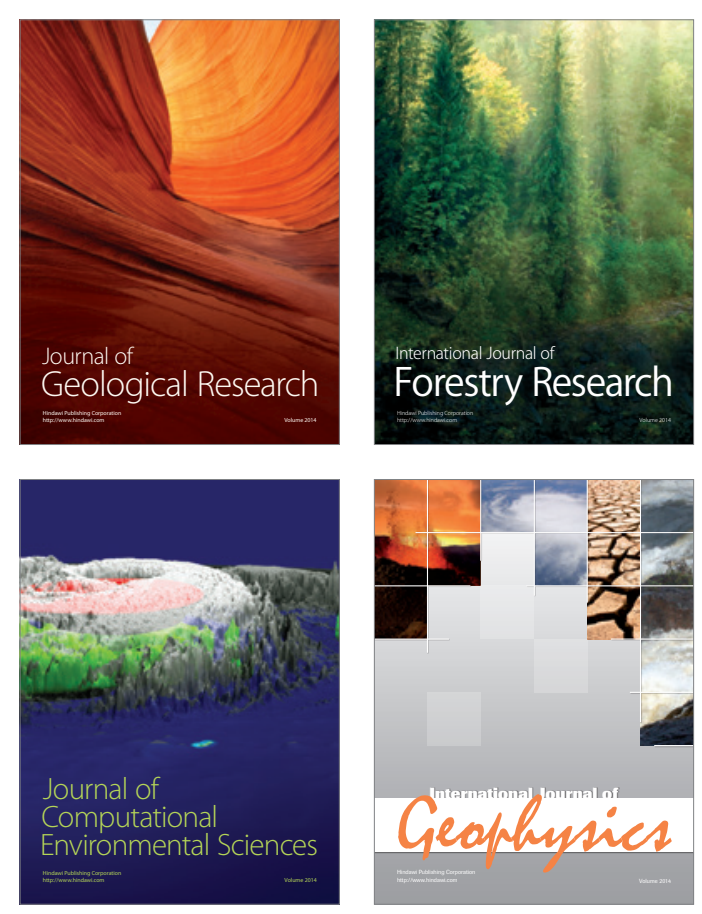
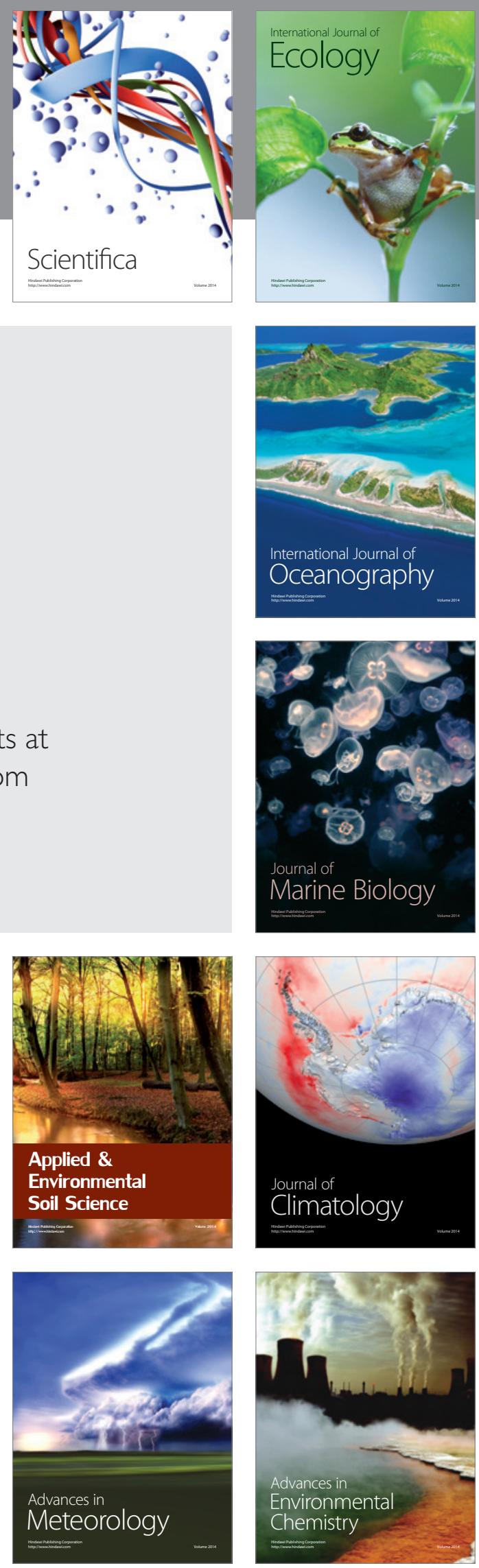